\title{
Respon Hematologi Ikan Nila (Oreochromis Niloticus) pada Suhu Pemeliharaan yang Berbeda
}

\author{
Saparuddin \\ Program Studi Pendidikan Biologi Fakultas Keguruan dan Ilmu Pendidikan Universitas Sembilanbelas \\ November Kolaka, Indonesia \\ e-mail : saparuddin.pbio@usn.ac.id
}

\begin{abstract}
Abstrak
Penelitian ini bertujuan untuk mengetahui pengaruh suhu media pemeliharaan yang berbeda terhadap respon hematologi ikan nila (Oreochromis niloticus) meliputi jumlah kadar glukosa darah, eritrosit,leukosit, dan trombosit. Metode yang digunakan dalam penelitian ini adalah metode eksperimental yang terdiri dari empat perlakuan yaitu kontrol (suhu $29^{\circ} \mathrm{C}$ ), A (suhu $\left.31^{\circ} \mathrm{C}\right), \mathrm{B}$ (suhu $\left.33^{\circ} \mathrm{C}\right)$ dan $\mathrm{C}\left(35^{\circ} \mathrm{C}\right)$ dengan masing-masing perlakuan diulang tiga kali.Berdasarkan hasil uji yang dilakukan pada suhu pemeliharaan yang berbeda diketahui bahwa ikan nila mengalami stres pada perlakuan $A, B$ dan $C$ dibandingkan dengan ikan kontrol. Hal ini ditandai dengan tingginya kadar glukosa darah hingga akhir pemeliharaan terdapat pada perlakuan $C\left(35^{\circ} \mathrm{C}\right)$ sebesar145,04 $\mathrm{mg} / \mathrm{dL}$. Nilai tertinggi total eritrositterdapat pada perlakuan $A\left(31^{\circ} \mathrm{C}\right)$ sebesar $3,36 \times 10^{6} \mathrm{sel} / \mathrm{ml}$. Total leukosit tertinggi terdapat pada perlakuan $C\left(35^{\circ} \mathrm{C}\right)$ sebesar7,08 $\times 10^{4} \mathrm{sel} / \mathrm{ml}$. Nilai tertinggi trombosit pada perlakuan $B\left(33^{\circ} \mathrm{C}\right) \mathrm{sebesar} 1,74 \times 10^{5} \mathrm{sel} / \mathrm{ml}$. Dapat disimpulkan bahwa peningkatan suhu air pada akuarium dapat menyebabkan stres pada ikan nila sehingga dapat mempengaruhi fisiologi hematologi normal ikan.
\end{abstract}

Kata Kunci: Hematologi, ikan Nila, Suhu

\section{PENDAHULUAN}

Ikan nila (Oreochromis niloticus) yang populer dengan sebutan 'tilapia" merupakan salah satu jenis ikan yang dibudidayakan di dunia. Salah satu contoh ikan yang sukses dibudidayakan di dunia adalah ikan nila yang berada pada urutan ketiga setelah salmon dan udang menurut Departemen Perikanan dan Akuakultur FAO (Food and Agriculture Organization) (Kordi, 2010). Ikan nila cocok dipelihara di dataran rendah sampai dataran tinggi $500 \mathrm{~m}$ dari permukaan laut (Cahyono, 2001). Kini ikan nila banyak dibudidayakan diberbagai daerah di Indonesia karena kemampuan adaptasi yang bagus di berbagai jenis air. Ikan nila dapat hidup di air tawar, air payau, dan air asin. Ikan nila juga tahan terhadap perubahan lingkungan, bersifat omnivora, dan mampu mencerna makanan secara efisien (suyanto, 2010).

Ikan nila dapat tumbuh dan berkembang dengan baik pada lingkungan perairan dengan kadar oksigen terlarut (dissolved oxygen) antara 2,0-2,5 mg/l. Menurut Mjoun dan Kurt (2010), suhu optimal bagi pertumbuhan ikan nila adalah antara $22-29^{\circ} \mathrm{C}$. Ikan nila terkenal sebagai ikan yang tahan terhadap perubahan lingkungan hidup (Suyanto, 2005). Joseph dan Sujatha (2010) melaporkan bahwa efek kenaikan suhu air pada $34^{\circ} \mathrm{C}$ selama 2 jam dapat menyebabkan stres pada ikan. Stres akibat peningkatan suhu air pada ikan berdampak terhadap performans dan kesehatan ikan berupa gangguan fungsi sel-sel darah (El-Sherif dan El-Feky, 2009). Menurut Docan et al. (2011) stres karena suhu tinggi berpengaruh terhadap hematologi ikan. Suhu juga berpengaruh terhadap parameter hematologi dan daya tahan terhadap penyakit (Engelsma et al., 2003). Hematologi sering digunakan untuk mendeteksi perubahan fisiologis yang disebabkan oleh stres lingkungan dan juga berhubungan dengan status kesehatan ikan (Al-Attar, 2005).

Iwama dan Nakanishi (1996) menyatakan bahwa nilai hematologi sangat berhubungan dengan kondisi patologis, terutama untuk memperoleh gambaran kondisi kesehatan ikan dalam keadaan sehat atau sakit. 
Penanganan dalam budidaya yang kurang baik dapat menyebabkan ikan mengalami stres, sehingga daya tahan tubuhnya menurun dan mudah terserang penyakit (Baticados dan Paclibare, 1992). Joseph dan Sujatha (2010) melaporkan bahwa efek kenaikan suhu air pada $34^{\circ} \mathrm{C}$ selama 2 jam dapat menyebabkan stres pada ikan. Stres akibat peningkatan suhu air pada ikan berdampak terhadap performans dan kesehatan ikan berupa gangguan fungsi sel-sel darah (El-Sherif dan El-Feky, 2009).

Wilayah Indonesia memiliki suhu dan kelembaban udara yang relatif tinggi. Pada tahun 2010 rata-rata suhu maksimum kabupaten Aceh Besar adalah $33,50^{\circ} \mathrm{C}$ dan suhu minimum $21^{\circ} \mathrm{C}$ (Badan Pusat Statistik, 2011).Suhu optimal bagi pertumbuhan ikan nila adalah antara 22-29 $\mathrm{C}$ (Mjoun dan Kurt, 2010). Suyanto (2005) menyatakan bahwa suhu optimal untuk pertumbuhan ikan nila antara $25-30^{\circ} \mathrm{C}$. Perubahan suhu dilingkungan media pemeliharaan dapat mempengaruhi kehidupan ikan bahkandapat menyebabkan stres. Suhu yang tinggi dapat menyebabkan dissolved oxygenmenurun dan mengurangi selera makan ikan (Kelabora, 2010). Meskipun ikandapat beraklimatisasi pada suhu yang relatif tinggi, tetapi pada suatu derajattertentu kenaikan suhu dapat menyebabkan kematian ikan. Perubahan drastis suhusampai mencapai $5^{\circ} \mathrm{C}$ dapat menyebabkan stres pada ikan atau membunuhnya (Cholik dkk., 1986). Kubilay and Ulukoy (2002) menyatakan bahwa stres adalahketidak mampuan suatu organisme mempertahankan kondisi homeostasis akibatterganggunya individu tersebut oleh adanya rangsangan dari luar yang dinamaidengan stressor.

Hematologi sering juga digunakan untuk mendeteksi perubahan fisiologis yang disebabkan oleh stres lingkungan dan juga berhubungan dengan status kesehatan ikan (Al-Attar, 2005). Parameter yang biasa menjadi indeks dalam menentukan status kesehatan ikan adalah total sel darah merah, sel darah putih, trombosit, sedangkan untuk melihat tingkat stres biasanya juga diukur kadar kortisol, dan glukosa darah. Kortisol, glukosa darah, hematokrit, jumlah sel darah merah dan jumlah sel darah putih merupakan indikator stres pada ikan.Berdasarkan latarbelakang yang telah dipaparkan maka perlu dilakukanpenelitian untuk mengetahui perubahan fisiologi hematologi ikan nilayang diberi perlakuan berupa peningkatan suhu media pembelajaran.

\section{METODE PENELITIAN}

Metode yang digunakan dalam penelitian ini adalah metode eksperimental yang terdiri dari empat perlakuan yaitu, Kontrol (K), A, B dan C dengan masing-masing perlakuan diulang sebanyak tiga kali kemudian data yang diperoleh disajikan secara deskriptif. Ikan nila pada Kontrol (K) dipelihara pada suhu ruangan $\left(29^{\circ} \mathrm{C}\right)$, pada perlakuan A ikan nila dipelihara pada suhu $31^{\circ} \mathrm{C}$, pada perlakuan B ikan nila dipelihara pada suhu $33^{\circ} \mathrm{C}$ dan pada perlakuan $\mathrm{C}$ ikan nila dipelihara pada suhu $35^{\circ} \mathrm{C}$. Pemeliharaan ikan nila pada penelitian ini dilakukan selama 15 hari. Ikan nila diberikan pakan komersil pada pagi, siang dan sore hari sebanyak 3\% dari bobot badan. Air akuarium diganti setiap tiga hari sekali sebanyak $30 \%$ dari total volume akuarium. Suhu dalam akuarium ditingkatkan secara bertahap dengan menggunakan heaterselama 4 jam.

\subsection{Persiapan Akuarium dan Ikan Sampel}

Akuarium yang digunakan berukuran $(40 \times 30 \times 30 \mathrm{~cm})$ diisi dengan menggunakan air tawar dengan volume $3 / 4$ bagian. Akuarium diberi aerasi dan diisi ikan nila sebanyak 5 ekor/akuarium dengan berat badan berkisar antara 40-50 gram. Namun, sebelum dipindahkan pada masing-masing akuarium terlebih dahulu dilakukan aklimatisasi selama 7 hari dan beri pakan ad libitum.

\subsection{Analisis Data}

Respon hematologi ikan terhadap suhu media pemeliharaan yang berbeda, dianalisis secara sidik ragam (ANOVA). Jika analisis menunjukkan berpengaruh nyata atau $F_{\text {hitung }}>F_{\text {tabel }}$, maka dilanjutkan dengan menggunakan Uji Beda Nyata Terkecil (BNT) pada taraf kepercayaan 95\%.

\section{HASIL DAN PEMBAHASAN}

Parameter hematologi yang diukur meliputi kadar glukosa darah, jumlah eritrosit, jumlah leukosit, dan jumlah trombosit. Selama pemaparan suhu yang berbeda pada perlakuan perlakuan A $\left(31^{\circ} \mathrm{C}\right)$, perlakuan B $(33$ 
$\left.{ }^{\circ} \mathrm{C}\right)$ dan perlakuan $\mathrm{C}\left(35^{\circ} \mathrm{C}\right)$. Sedangkan Perlakuan kontrol diberikan sihu optimum $\left(29^{\circ} \mathrm{C}\right)$. Hasil pengamatan hematologi dapat dilihat pada Tabel 1.

Tabel 1 Rata-rata jumlah kadar glukosa darah, jumlah eritrosit, jumlah leukosit, dan jumlah trombosit ikan nila setelah 15 hari pemaparan dengan suhu yang berbeda.

\begin{tabular}{|l|l|l|l|l|}
\hline Suhu Media & \multirow{2}{*}{$\begin{array}{l}\text { Kadar Glukosa darah } \\
(\mathrm{mg} / \mathrm{dL})\end{array}$} & Eritrosit & Leukosit & Trombosit \\
\cline { 3 - 5 } & $\left(10^{6} \mathrm{sel} / \mathrm{ml}\right)$ & $\left(10^{6} \mathrm{sel} / \mathrm{ml}\right)$ & $\left(10^{5} \mathrm{sel} / \mathrm{ml}\right.$ \\
\hline Kontrol $\left(29^{\circ} \mathrm{C}\right)$ & $113,38 \pm 3,10^{\mathrm{a}}$ & $3,56 \pm 0,02^{\mathrm{a}}$ & $4,79 \pm 0,55^{\mathrm{a}}$ & $1,48 \pm 0,04^{\mathrm{a}}$ \\
\hline $\mathrm{A}\left(31^{\circ} \mathrm{C}\right)$ & $136,42 \pm 1,30^{\mathrm{ab}}$ & $3,16 \pm 0,17^{\mathrm{b}}$ & $6,13 \pm 0,11^{\mathrm{b}}$ & $1,49 \pm 0,14^{\mathrm{b}}$ \\
\hline $\mathrm{B}\left(33^{\circ} \mathrm{C}\right)$ & $135,46 \pm 3,51^{\mathrm{bc}}$ & $3,06 \pm 0,07^{\mathrm{bc}}$ & $6,07 \pm 0,54^{\mathrm{b}}$ & $1,57 \pm 0,18^{\mathrm{bc}}$ \\
\hline $\mathrm{C}\left(35^{\circ} \mathrm{C}\right)$ & $142,60 \pm 2,44^{\mathrm{c}}$ & $3,10 \pm 0,05^{\mathrm{c}}$ & $6,72 \pm 0,36^{\mathrm{bc}}$ & $1,56 \pm 0,18^{\mathrm{c}}$ \\
\hline
\end{tabular}

\subsection{Jumlah Kadar Glukosa Darah}

Glukosa darah merupakan sumber pasokan bahan bakar utama dan substrat esensial untuk metabolisme sel terutama sel otak (stewar, 1991). Pada hewan poikilotermik termasukm ikan nila, perubahan suhu lingkungan akan berpengaruh langsung terhadap proses metabolisme. Volume darah pada ikan berkisar 1,5-3 $\%$ dari bobot tubuh. Kadar glukosa darah ikan yang normal mengandung 40-90 mg/dl, kandungan glukosa darah tersebut hampir sama dengan glukosa darah pada manusia yaitu 70-110 mg/dl (Rahardjo, et al., 2011).

Hasil pengukuran kadar glukosa darah ikan nila yang dipeliharapada suhu yang berbeda mengalami peningkatan. Kadar glukosa darah ikan yangdipelihara pada perlakuan $\mathrm{A}\left(31^{\circ} \mathrm{C}\right)$, B $\left(33^{\circ} \mathrm{C}\right)$ dan $\mathrm{C}\left(35^{\circ} \mathrm{C}\right)$ lebih tinggi dibandingkan ikan yang dipelihara pada suhu perlakuan kontrol (suhu $\left.29^{\circ} \mathrm{C}\right)$. Peningkatan kadar glukosa darah ikan uji pada perlakuan $\mathrm{A}\left(31^{\circ} \mathrm{C}\right)$ hingga hari ke-15 mencapai $137,56 \mathrm{mg} / \mathrm{dL}$, pada perlakuan $\mathrm{B}\left(33^{\circ} \mathrm{C}\right)$ mencapai $138,98 \mathrm{mg} / \mathrm{dL}$, dan perlakuan $\mathrm{C}\left(35^{\circ} \mathrm{C}\right)$ mencapai $145,04 \mathrm{mg} / \mathrm{dL}$.

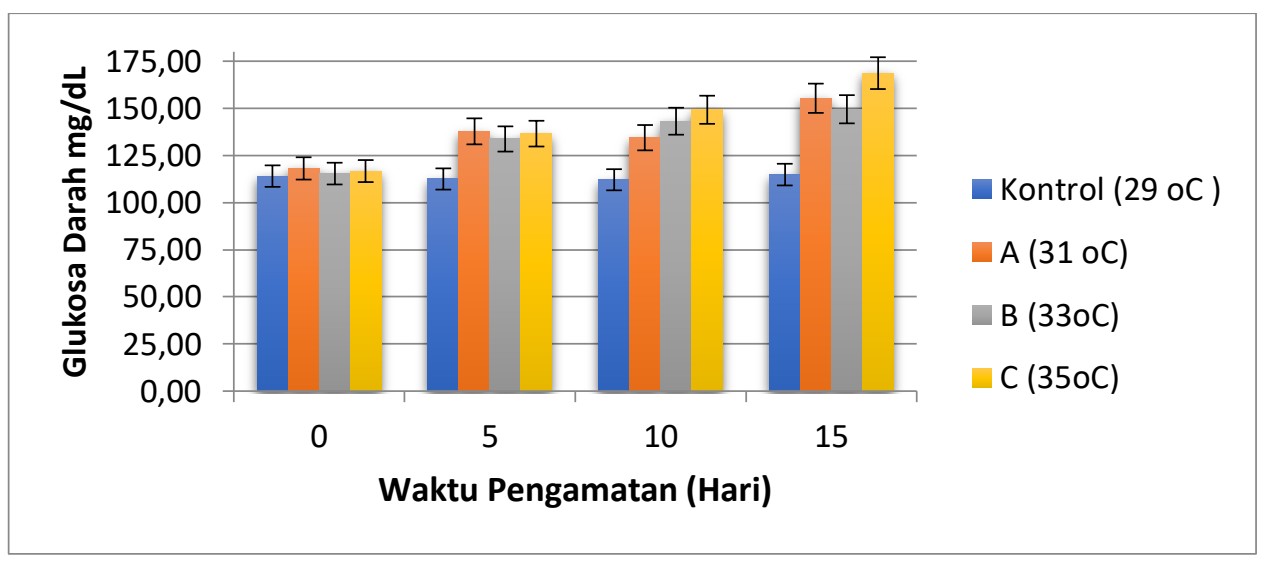

Gambar 1 Rata-rata jumlah kadar glukosa darah selama 15 hari pada peningkatan suhu media pemeliharaan.

\subsection{Jumlah Eritrosit}

Eritrosit adalah cakram bikonkaf tidak berinti yang berdiameter $\pm 8 \mu \mathrm{m}$, tebal bagian tepi $2 \mu \mathrm{m}$ dan ketebalan bagian tengah menjadi $1 \mu \mathrm{m}$. Komponen utama eritrosit adalah hemoglobin protein yang mengangkut sebagian besar oksigen $\left(\mathrm{O}_{2}\right)$ dan sebagian kecil fraksi karbon dioksida $\left(\mathrm{CO}_{2}\right)$. Hasil pengukuran eritrosit ikan nila pada perlakuan $\mathrm{A}\left(31^{\circ} \mathrm{C}\right), \mathrm{B}\left(33^{\circ} \mathrm{C}\right)$ dan $\mathrm{C}\left(35^{\circ} \mathrm{C}\right)$ mengalami penurunan pada hari ke-5, ke-10 dan ke-15. Nilai rata-rata eritrosit dari perlakuan kontrol $\left(29^{\circ} \mathrm{C}\right) 3,56 \times 10^{6}$ sel/ml. Nilai rata-rata pada perlakuan A $\left(31^{\circ} \mathrm{C}\right)$, B $\left(33^{\circ} \mathrm{C}\right)$, dan Perlakuan $\mathrm{C}\left(35^{\circ} \mathrm{C}\right)$ berturut-turut sebesar $3,16 \times 10^{6} \mathrm{sel} / \mathrm{ml}, 3,06 \times 10^{6} \mathrm{sel} / \mathrm{ml}$, dan $3,10 \times 10^{6} \mathrm{sel} / \mathrm{ml}$, lebih rendah dari perlakuan kontrol. Dari hasil penelitian ini menunjukkan bahwa rata-rata jumlah eritrosit ikan yang diperoleh dari 
perlakuan kontrol $\left(29^{\circ} \mathrm{C}\right)$ berada pada kisaran normal. Hal ini sesuai dengan yang dilaporkan oleh andayani, S. dkk., (2008) bahwa jumlah rata-rata ikan nila yaitu sekitar 3,56 x 106 $\mathrm{sel} / \mathrm{ml}$.

Hasil penelitian ini berbeda dengan hasil yang diteliti oleh Bozorgnia et al. (2011) menyebutkan bahwa meningkatnya suhu maka jumlah eritrosit meningkat. Ketika suhu meningkat maka aktivitas penyerapan oksigen oleh eritrosit meningkat. Tubuh ikan mengompensasi perubahan kekurangan oksigen tersebut dengan meningkatkan jumlah eritrosit. Pendapat dari Bozorgnia et al. (2011) juga sesuai dengan pendapat dari Ravichandra (2012) yang menyatakan bahwa pada suhu tinggi jumlah eritrosit pada ikan meningkat karena untuk mengurangi keadaan stress maka ikan akan menyesuaikan kondisi fisiologisnya dengan meningkatkan jumlah eritrosit dalam darah.

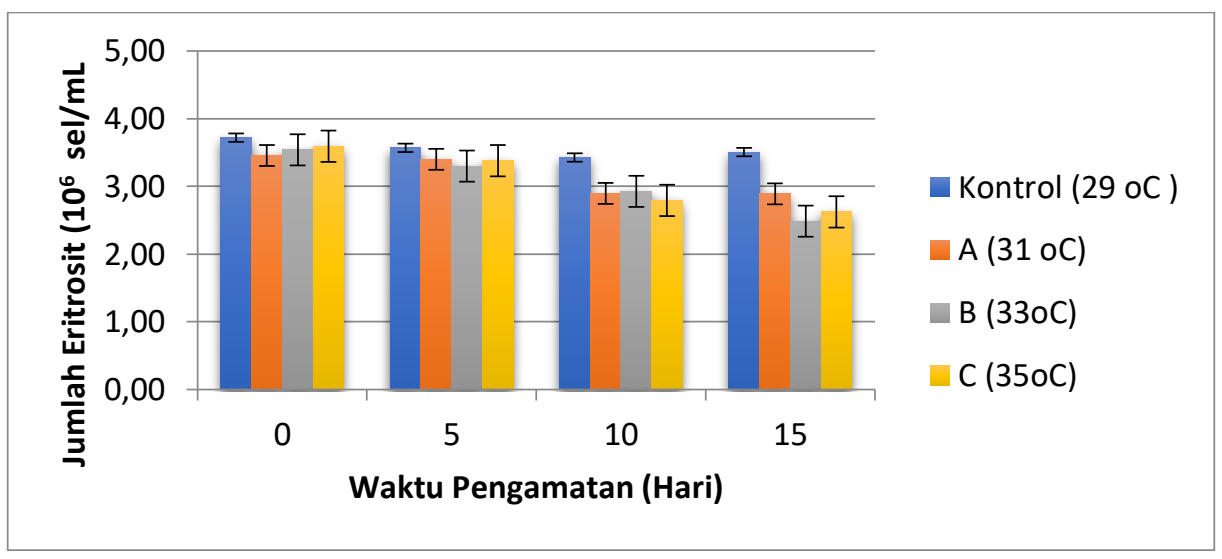

Gambar 2 Rata-rata jumlah eritrosit ikan nila selama 15 hari pada peningkatan suhu media pemeliharaan.

Perbedaan hasil penelitian ini diduga disebabkan karena adanya perbedaan perlakuan. Pada perlakuanyang dilakukan oleh Bozorgnia et al. (2011) dan Ravichandra (2012) merupakan perlakuan peningkatan suhu panas secara akut, sedangkan yang peneliti lakukan merupakan peningkatan suhu panas secara berkelanjutan dan bertahap selama 15 hari. Rendahnya rata-rata jumlah eritrosit pada perlakuan P2 dan P3 diduga karena ada faktor lain yang memengaruhi kondisi fisiologis ikan. 3.3 Jumlah Leukosit

Leukosit pada ikan teleostei merupakan salah satu bagian dari sistem pertahanan tubuh yang bersifat non-spesifik (Uribe dkk., 2011). Menurunya jumlah leukosit disebut leukopenia sedangkan meningkatnya jumlah leukosit disebut leukositosis. Leukosit yang diproduksi akan tinggi jika terdapat infeksi virus pada tubuh ikan dan terdapat upaya dari tubuh ikan tersebut untuk melawan (Azhar, 2013).

Hasil pengukuran leukosit ikan nila pada perlakuan A $\left(31{ }^{\circ} \mathrm{C}\right)$, B $\left(33^{\circ} \mathrm{C}\right)$ dan $\mathrm{C}\left(35^{\circ} \mathrm{C}\right)$ selama pemeliharaan mengalami peningkatan dibandingkan dengan kontrol $(\mathrm{K})$, jumlah total leukosit tertinggi diperoleh dari ikan perlakuan $\mathrm{C}\left(35^{\circ} \mathrm{C}\right)$ pada pengamatan hari ke-15 yaitu sebesar $6,72 \times 10^{4} \mathrm{sel} / \mathrm{ml}$.

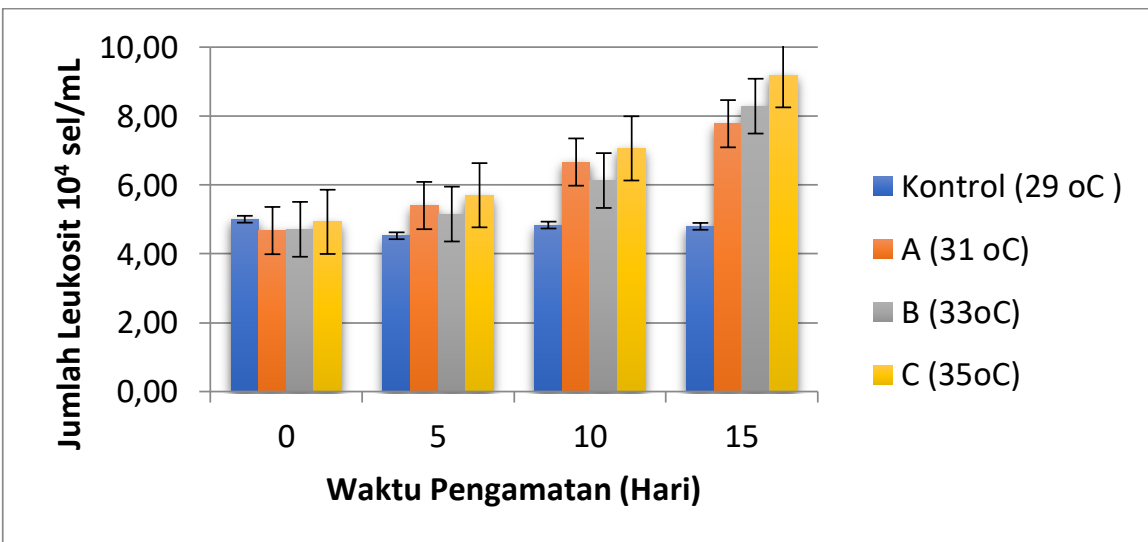

Gambar 3 Rata-rata jumlah leukosit ikan nila selama 15 hari pada peningkatan suhu media pemeliharaan. 
Nilai rata-rata leukosit dari perlakuan kontrol $\left(29^{\circ} \mathrm{C}\right)$ sebesar $4,79 \times 10^{4} \mathrm{sel} / \mathrm{ml}$. Nilai rata-rata pada perlakuan A $\left(31^{\circ} \mathrm{C}\right), \mathrm{B}\left(33^{\circ} \mathrm{C}\right)$, dan Perlakuan $\mathrm{C}\left(35^{\circ} \mathrm{C}\right)$ berturut-turut sebesar $6,13 \times 10^{4} \mathrm{sel} / \mathrm{ml}, 6,07 \times 10^{4}$ $\mathrm{sel} / \mathrm{ml}$, dan $6,72 \times 10^{4} \mathrm{sel} / \mathrm{ml}$, lebih tinggi dari perlakuan kontrol. Peningkatan jumlah leukosit ini terkait dengan kinerja sistem imun ikan dalam mereduksi tekanan media pemeliharaan yang panas. Rata-rata jumlah leukosit ikan yang diperoleh dari perlakuan kontrol $\left(29^{\circ} \mathrm{C}\right)$ berada pada kisaran normal. Hal ini sesuai dengan yang dilaporkan oleh andayani, S. dkk., (2010) bahwa jumlah rata-rata leukosit ikan nila yaitu sekitar 4,65 x $10^{4} \mathrm{sel} / \mathrm{ml}$.

\subsection{Jumlah Trombosit}

Trombosit atau keping-keping darah berperan penting dalam proses pembekuan darah. Roberts dan Richards (1978) menyatakan bahwa trombosit mengeluarkan tromboplastin yaitu enzim yang membuat polimeri dan fibrinogen yang berperan penting dalam pembekuan darah. Ketika endotelium pembuluh dan jaringan ikat rusak maka trombosit menempel keserat kolagen dalam jaringan ikat tersebut dan mengeluarkan zat yang membuat trombosit yang saling berdekatakan menjadi lengket dan membentuk sumbat sehingga darah tidak keluar. Penggumpalan membentuk aktivator yang disebut protrombin kebentuk aktifnya disebut trombin.

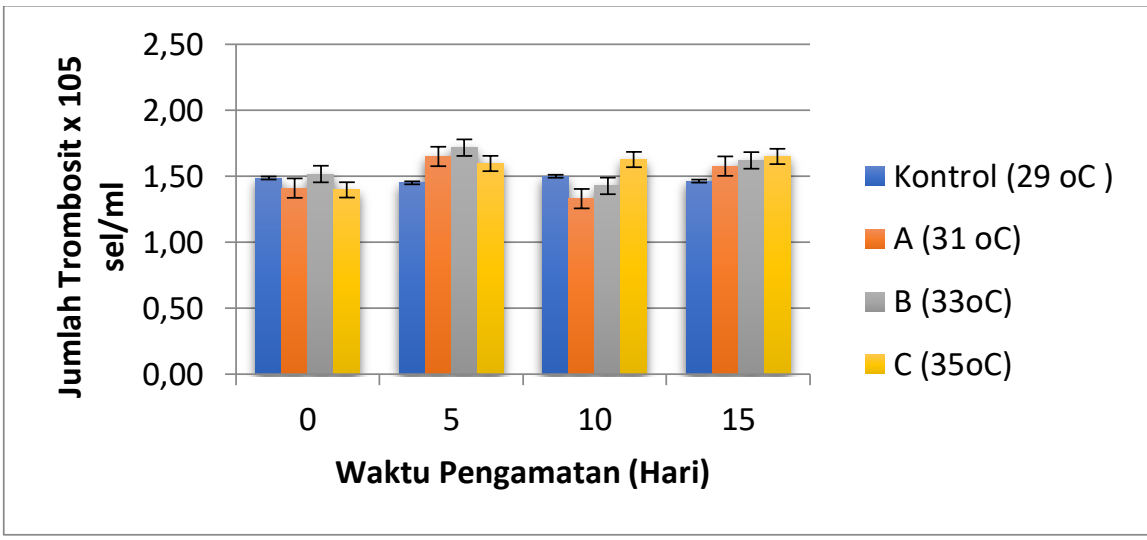

Gambar 4 Rata-rata jumlah eritrosit ikan nila selama 15 hari pada peningkatan suhu media pemeliharaan.

Hasil yang ditunjukkan memperlihatkan bahwa jumlah trombosit pada ikan nila tidak ada perbedaan yang signifikan antar perlakuan setelah diberikan suhu media pemeliharaan yang berbeda.Kenyataan ini menunjukkan bahwa jumlah trombosit ikan nila tidak terpengaruh oleh adanya penambahan suhu media pemeliharaan.Hal ini berdasarkan hasil penelitian Saparuddin, dkk (2017) menyatakan bahwa peningkatan atau penurunan jumlah trombosit berhubungan dengan pendarahan pada organ ikan. sehingga penambahan suhu media pemeliharaan ikan nila tidak menyebabkan peningkatan atau penurunan jumlah trombosit.

\section{KESIMPULAN}

Dari hasil penelitian ini dapat disimpulkan bahwa peningkatan suhu $31^{\circ} \mathrm{C}, 33^{\circ} \mathrm{C}$ dan $35^{\circ} \mathrm{C}$ selama 15 hari dapat meningkatkan kadar glukosa darah, jumlah leukosit, dan menurunkan jumlah eritrosit ikan nila.

\section{DAFTAR PUSTAKA}

Al-Attar, A.M. 2005. Changes in haematological parameters of the fish, Oreochromis niloticus treated with sublethal concentration of cadmium. Pakistan J. of Biol. Sciences. 8(3):421-424.

Andayani, Marsoedi, Sanoesi, wilujeng, dan Suprastiani. (2008) : Profil hematologi beberapa species ikan air tawar budidaya. Jurusan MSP, Fakultas Perikanan dan Kelautan UB Malang.

Azhar, F. (2013) : Pengaruh pemberian probiotik dan prebiotik terhadap performan juvenil ikan kerapu bebek (cromileptes altivelis). Laboratorium kesehatan ikan, Institut Pertanian Bogor. Bogor 16680. 
https://jurnal.unsulbar.ac.id/index.php/saintifik

Bozorgnia, A., A. Alimohammadi, and M. Hosseinifard. 2011. Acute Effects of Different Temperature in the Blood Parameters of Common Carp (Cyprinus carpio). Second International Conference on Environmental Science and Technology IPCBEE vol.6. IACSIT Press, Singapore:V252-V255.

Cahyono, B. 2001. Budidaya Ikan di Perairan Umum. Penerbit Kanisius, Yogyakarta.

Docan, A.V., V. Cristea, and D. Lorena. 2011. Influence of Thermal Stress on the Hematological Profile of Oncorhynchus mykiss Heldin Different Stocking Densitiesin Recirculating Aquaculture Systems. Environmental Sciences and Cadastre Department, "Dunarea de Jos" University of Galati, Romania.

El-Sherif, M.S. dan A.M.I. El-Feky. 2009. Performanceof nile tilapia (Oreochromis niloticus) fingerlings. II. Influence of different water temperature. Int. J. Agric. Biol.11:301-305.

Engelsma, M.Y., S. Hougee, D. Nap, M. Hofenk, J. Rombout, and W.B. Muiswinkel. 2003. Multiple acute temperature stress affects leucocyte populations and antibody responses in common carp, Cyprinus carpio L. J. Fish. Shellfish. Immunol. 15:397410.

Iwama, G. dan T. Nakanishi. 1996. The Fish Immune System. Academic Press, London.

Joseph, J.B and S.S. Sujatha. 2010. Real-time quantitative (PCR) applications to quantify and the expression profiles of heat shock protein (HSP70) genes in Nile tilapia, Oreocrhomisniloticus (L.) and Oreocrhomis mossambicus (P.). Int. J. Fish. Aquac. 2(1):044-048.

Kordi, M.G.H. 2010. Budi Daya Ikan Nila di Kolam Terpal. Edisi 1. Penerbit Andi, Yogyakarta.

Mjoun, K. and A.R. Kurt. 2010. Tilapia: Profile and Economic Importance. South Dakota Cooperative Extension Service. 1:1-4.

Rahardjo, M. F., Sjafei, D. S., Affandi, R., \& Sulistiono (2011). Ikhtiologi. Jakarta : Lubuk Agung.

Ravichandra, J. A. 2012. Influence of acute temperature stress on hemoglobin content in snakeheaded fish (Channa punctatus) Gavari River, Nanded, India. Int. J. Biomed. Adv. Res. 3(11):1-5.

Roberts, R.J. dan Richards, R.H. (1978) : The Bacteriology of Teleost in Fish Pathology. Roberts RJ, editor. Bailliere Tindal Book Publ, London. 205-308p.

Saparuddin, A. Ridwan dan Z. Arham. 2017. Efektivitas Ekstrak Daun Macaranga tanarius Dalam Menginaktifasi Viral Nervous Necrosis Ikan Kerapu Tikus. Biowallancea, Vol.4 No. 1. Hal 519-526.

Steward, M. 1991. Animal Physiology. Thomson Litho Ltd., London. 486 p.

Suyanto, S.R. 2005. Nila. Penerbit Swadaya, Bogor.

Suyanto, S.R. 2010. Pembenihan dan Pembesaran Ikan Nila.Penerbit Swadaya, Jakarta.

Uribe, C., Folch, H., Enriquez, R. dan Moran, G. (2011) : Innate and adaptive immunity in teleost fish: a review . Veterinarni Medicina 56 (10) : 486-503. 